\title{
THE EFFECT OF DIODRAST ON THE NORMAL URIC ACID CLEARANCE ${ }^{1}$
}

\author{
By ROY W. BONSNES, LESLIE V. DILL, 2 AND ETHEL S. DANA \\ (From the Department of Obstetrics and Gynecology, Cornell University Medical College, and the \\ New York Hospital, New York City)
}

(Received for publication March 6, 1944)

Uric acid clearances in man have been determined by several investigators. The values reported have ranged from 6.9 to 31.9 cc. per minute. This highest value was recently reported by one group from this laboratory (1). Subsequent attempts by us to confirm this figure have been unsuccessful. The values now obtained for uric acid clearances average about 15 cc. per minute or about one-half the value previously reported.

Many possible explanations for this discrepancy presented themselves. First, a different method is now being used for the determination of uric acid. However, the methods have been carefully checked. They give nearly identical results. And second, the uric acid clearances performed previously in this laboratory were determined upon specimens of urine and blood, obtained from patients who were also receiving inulin and diodrast, while in the later studies, inulin and diodrast were absent. The presence of either one of these substances might, therefore, alter the normal excretion of uric acid and/or affect the determination of uric acid.

It was readily determined that inulin and diodrast do not interfere with the determination of uric acid by the methods used in these experiments when these substances are added directly to the urine in quantities such that the final concentration is of the same order of magnitude as that found in the urine in clearance studies.

It would also appear that the presence of inulin in the subject does not affect the uric acid clearance since Coombs et al. (2) have observed an average uric acid clearance in 8 normal nonpregnant humans of $11.1 \mathrm{cc}$. per minute per 1.73 sq. $\mathrm{m}$. when inulin was given simultaneously.

These observations tend to indicate that the

1 This study was aided by a grant from the John and Mary R. Markle Foundation.

Now, Lieutenant L. V. Dill, U. S. N. high values for the uric acid clearances previously reported from this laboratory might be due to the simultaneous presence and excretion of diodrast. The following experiments were therefore carried out to test this hypothesis. First, we determined the effect of urine flow upon the uric acid clearance using our methods, since it is easier to obtain satisfactory urine collections for clearance determinations in the postpartum female if the urine flow is high. These experiments also assured us that we could measure the uric acid satisfactorily in very dilute urines. We then studied the effect of the injection of large quantities of glucose upon the uric acid clearance in order to determine if the reabsorption of supranormal amounts of glucose by the kidney tubule has any effect upon the uric acid clearance. We finally studied the effect of diodrast upon the uric acid clearance. Preliminary studies showed that diodrast did affect the excretion of uric acid. This effect was therefore studied in a separate series of cases.

\section{SUBJECTS AND METHODS}

Clinically normal women in their 1st to 8th postpartum day were used as experimental subjects. In the series of patients used to study the effect of water diuresis and glucose upon the uric acid clearance, sufficient water was given to insure an adequate flow. However, we also attempted to get a distribution of flows. In this series, the first clearance period was started about 9 a.m. In most cases (i.e. when the flow was high), the patients were not catheterized. Each clearance period averaged about 45 minutes. There were either 2 or 3 consecutive periods on the same day for each patient. Blood was drawn, either in the middle of the 2 nd if there were 3 periods, or at the end of the 1 st if there were 2 periods.

In the series of patients used for the diodrast study, the conditions were more rigidly controlled. At about 6 a.m., on their 4th to 6th postpartum day, the patients were given sufficient water over the period of an hour to insure an adequate urine flow. Breakfast was withheld. At approximately 7 a.m., the patient was catheterized and the urine specimen was discarded. The urine was then collected for 2 consecutive one-half hour periods. A blood 
specimen was taken after the first half-hour period. The uric acid and urea clearances were determined upon these specimens. From these data, the control clearances were calculated. On the following day, the same procedure was carried out. In addition, however, each patient was given an intravenous injection of 5 cc. of 35 per cent diodrast ${ }^{8}$ at the beginning of each half-hour period. Diodrast was not determined. It has been assumed that the greater part of the diodrast given would be excreted in one-half hour (3) and that the blood levels of diodrast at this point would be low. The urine specimens were also analyzed for creatinine to be sure that the collection of the urine had been satisfactory. In this series, only those data have been used which showed satisfactory checks with respect to uric acid and urea clearances and creatinine excretion.

All clearances were calculated as maximum clearances, except in one instance (a urea clearance) which is indicated in the last table. Plasma values are used for the calculation of uric acid clearances. Whole blood urea values are used for the calculation of urea clearances.

Plasma uric acid was determined on Wu filtrates (4) by the method described below. Urine uric acid was determined on diluted urine by the same method. Urea in the blood and urine was determined by the manometric hypobromite method of Van Slyke and Kugel (5). Creatinine in the urine was determined by the Folin method (6). A Klett-Summerson photoelectric colorimeter (7) was used for the determination of all color densities.

\section{RESULTS}

Uric acid methods. Before these particular experiments were started, it had been found that the method previously used for the determination of uric acid (the Folin 1933 method (8) using the Folin 1934 reagent (9)) was not entirely satisfactory in our hands. The Folin 1922 method (10) which has been used for the determination of uric acid in the routine laboratory of this clinic for many years was substituted. This determination is carried out by essentially the same procedure described by Folin in 1922 except that the Folin-Marenzi reagent (11) is used and the lithium sulfate is omitted. This method will be referred to as the 1922 method.

When the discrepancy in the uric acid clearances became apparent, it became necessary to determine whether or not the 2 methods were measuring essentially the same thing. They were, therefore, compared. Simultaneous determinations by the 2 methods on the same filtrate of the uric acid content of 37 different Folin-Wu

\footnotetext{
${ }^{3}$ The product sold by the Winthrop Chemical Company, Inc., New York, N. Y.
}

TABLE I

Urine uric acid as determined by the Folin 1922 and the Folin 1933 methods

\begin{tabular}{c|c|c|c}
\hline \multirow{3}{*}{ Urine no. } & \multirow{2}{*}{ Urine dilution } & \multicolumn{2}{|c}{ Uric acid } \\
\cline { 3 - 4 } & & 1922 method & 1933 method \\
\hline & & \multicolumn{2}{|c}{ mgm. per cent } \\
& & 55.5 & 57.8 \\
1 & $1: 200$ & 52.7 & 56.9 \\
2 & $1: 100$ & 32.4 & 37.8 \\
3 & $1: 200$ & 30.3 & 30.8 \\
4 & $1: 100$ & 11.6 & 11.3 \\
5 & $1: 50$ & 13.8 & 14.4 \\
& $1: 50$ & 15.7 & 14.6 \\
\hline
\end{tabular}

filtrates of whole blood showed that the results obtained with the 1922 method averaged 0.5 mgm. per cent lower than those obtained with the 1933 method. The whole blood uric acid values ranged from 1.8 to $5.4 \mathrm{mgm}$. per cent (1922 method). Uric acid was also estimated in the same plasma filtrates by the 2 methods. On 17 different $\mathrm{Wu}$ plasma filtrates, the results obtained with the 1922 method averaged $0.2 \mathrm{mgm}$. per cent lower than those obtained with the 1933 method. A similar study with several different urines at various dilutions showed that the uric acid values obtained by the 2 methods were of the same order of magnitude (Table I).

When inulin and diodrast are added to the urines or blood filtrates in the concentrations in which they are present in these studies, they have no effect upon the determination of uric acid. It seems, therefore, that inulin and diodrast interference with the determination of uric acid cannot account for the observed results.

There is some evidence which indicates that these methods are measuring uric acid (urate). Schaffer $(12,13)$ has shown that the substance in blood filtrates which produces 86 to 96 per cent of the color and the substance in urine which produces 94 to 98 per cent of the color, when the Folin 1933 method is used for the determination of uric acid, is destroyed when portions of such blood filtrates and urines are incubated with a defatted, desiccated kidney preparation which has uricase activity. Since the 1922 method gives slightly lower results with blood and plasma filtrates compared with the Folin 1933 method, and essentially the same results when the 1922 method is used for urines, it can be assumed that 
both these methods are measuring mainly uric acid.

Effect of urine flow. With urine flows from 0.83 to $13.9 \mathrm{cc}$. per minute per 1.73 sq. m., the mean uric acid clearance obtained from 29 clearance periods on 9 subjects averages $15.4 \pm 3.2^{4}$ cc. per minute per 1.73 sq. m., with a range of values from 9.0 to $20.6 \mathrm{cc}$. per minute. The best straight line which describes these data is described by the equation $\mathrm{y}=14.97 \pm 0.067 \mathrm{x}$ with the S.E.xy $=3.21$ cc. The co-efficient of correlation equals 0.076 . There is, therefore, no significant correlation between the uric acid clearance and the urine flow. There is also no indication that an augmentation level exists at these urine flows.

This evidence can, therefore, be taken to indicate that the uric acid method used will estimate the uric acid when it is present in very low concentration, since these data confirm previous observations that the uric acid excretion is independent of the urine flow.

Effect of glucose. In order to determine the effect of the injection of a large quantity of glucose upon the uric acid clearance, the patient was given $50 \mathrm{cc}$. of 50 per cent glucose, intravenously. Either 2 or 3 clearance periods were obtained after a single injection of glucose. The average value for the uric acid clearance (11 clearance periods on 4 different patients) following the intravenous administration of glucose was $\mathbf{1 5 . 9}$ cc. per minute per 1.73 sq. m., with a range of from 8.4 to $20.3 \mathrm{cc}$. per minute. There is no definite trend to be observed in the uric acid clearance following the injection of glucose. A trend might be expected if the glucose were affecting the uric acid clearance, since it can be assumed that the blood glucose at the time of injection attained a maximum level which constantly decreased. These data indicate that glucose in massive doses has no effect upon the uric acid clearance, since the clearances obtained after the injection of glucose were not significantly different from those obtained with water diuresis.

Effect of diodrast. In another series of 11 patients, an average normal uric acid clearance of

$$
\sqrt{\frac{\Sigma(\Delta)^{2}}{N-1}}
$$

$14.0 \pm 2.9$ cc. per minute per 1.73 sq. m. was obtained. When diodrast was given, as outlined above, to these same patients, on the next day the uric acid clearance averaged $50.6 \pm 9.1 \mathrm{cc}$. The difference between these means, divided by the standard deviation of the means, equals 17.2.

Urea clearances performed on the same specimens of blood and urine averaged for the control day $76.2 \pm 13.0 \mathrm{cc}$. per minute per 1.73 sq. $\mathrm{m}$. and for the day on which diodrast was given, $82.9 \pm 12.0 \mathrm{cc}$. per minute. The difference between these means, divided by the standard deviation of the means, equals 1.66. There is, therefore, no significant difference between the means. These data are presented in Tables II and III.

The creatinine excreted per 30 minutes per 1.73 sq. $\mathrm{m}$. on the control day averaged $24 \pm 1.7$ $\mathrm{mgm}$. and on the day diodrast was given, $23 \pm 2.4$ mgm. The difference between these means, divided by the standard deviation of the means, equals 0.66 . There is again no significant difference between the excretion of creatinine on the day on which diodrast was given and that on the day diodrast was not given.

The evidence presented shows that diodrast exerts an effect upon the excretion of uric acid. It will be noted that there is no appreciable change in the blood uric acid from one day to the next. The diodrast has no effect upon the excretion of urea and creatinine.

\section{DISCUSSION}

The normal uric acid clearance herein reported for the normal postpartum woman is approximately of the same order of magnitude as most of the uric acid clearances reported, or calculated from data reported in that literature on uric acid excretion which presents sufficient data for the calculation of clearances.

The uric acid clearances as calculated by us $^{5}$ from the data of Berglund and Frisk (14) on uric

\footnotetext{
- Berglund and Frisk do not calculate a clearance. The data for these calculations have been selected from their data. Only those data have been used which were obtained during the first period, before any experimental manipulations were performed. A clearance calculated from the "elimination index" of Berglund and Frisk equals 19.1 cc. per minute (see Bröchner-Mortensen (18 to 20)).
} 
TABLE II

Uric acid clearances

\begin{tabular}{|c|c|c|c|c|c|c|c|c|c|c|}
\hline No. & Patient & Treatment & $\begin{array}{c}\text { Surface } \\
\text { area }\end{array}$ & $\begin{array}{c}\text { Post- } \\
\text { partum }\end{array}$ & $\mathbf{v}$ & $\mathrm{U}$ & $\mathbf{P}$ & $\mathrm{U} / \mathrm{P}$ & c & Corrected \\
\hline \multirow{3}{*}{1} & & & sq. $m$. & days & $c c$. & $m g m$ & ient & & $c c . p c$ & minute \\
\hline & D. D. & Control & 1.58 & 5 & $\begin{array}{l}10.0 \\
11.7\end{array}$ & $\begin{array}{l}6.9 \\
6.8\end{array}$ & $\begin{array}{l}4.9 \\
4.9\end{array}$ & $\begin{array}{l}1.41 \\
1.39\end{array}$ & $\begin{array}{l}14.1 \\
16.3\end{array}$ & $\begin{array}{l}15.4 \\
17.8\end{array}$ \\
\hline & & Diodrast & & 6 & $\begin{array}{r}10.0 \\
8.7\end{array}$ & $\begin{array}{l}19.8 \\
26.4\end{array}$ & $\begin{array}{l}5.0 \\
5.0\end{array}$ & $\begin{array}{l}3.96 \\
5.3\end{array}$ & $\begin{array}{l}39.6 \\
45.9\end{array}$ & $\begin{array}{l}43.3 \\
50.0\end{array}$ \\
\hline \multirow[t]{2}{*}{2} & M.P. & Control & 1.77 & 5 & $\begin{array}{l}11.7 \\
15.7\end{array}$ & $\begin{array}{l}4.0 \\
3.7\end{array}$ & $\begin{array}{l}3.1 \\
3.1\end{array}$ & $\begin{array}{l}1.29 \\
1.19\end{array}$ & $\begin{array}{l}15.1 \\
18.7\end{array}$ & $\begin{array}{l}14.7 \\
18.3\end{array}$ \\
\hline & & Diodrast & & 6 & $\begin{array}{l}17.5 \\
13.2\end{array}$ & $\begin{array}{r}8.7 \\
11.9\end{array}$ & $\begin{array}{l}2.8 \\
2.8\end{array}$ & $\begin{array}{l}3.11 \\
4.25\end{array}$ & $\begin{array}{l}54.4 \\
56.1\end{array}$ & $\begin{array}{l}53.1 \\
54.7\end{array}$ \\
\hline \multirow[t]{2}{*}{3} & R. D. & Control & 1.89 & 6 & $\begin{array}{r}12.5 \\
7.0\end{array}$ & $\begin{array}{l}3.6 \\
7.4\end{array}$ & $\begin{array}{l}4.7 \\
4.7\end{array}$ & $\begin{array}{l}0.76 \\
1.58\end{array}$ & $\begin{array}{r}9.6 \\
11.0\end{array}$ & $\begin{array}{r}8.8 \\
10.1\end{array}$ \\
\hline & & Diodrast & & 7 & $\begin{array}{l}15.1 \\
11.6\end{array}$ & $\begin{array}{l}15.1 \\
18.8\end{array}$ & $\begin{array}{l}4.4 \\
4.4\end{array}$ & $\begin{array}{l}3.44 \\
4.27\end{array}$ & $\begin{array}{l}51.7 \\
49.5\end{array}$ & $\begin{array}{l}47.4 \\
45.3\end{array}$ \\
\hline \multirow[t]{2}{*}{4} & c. 0 . & Control & 1.51 & 5 & $\begin{array}{l}1.01 \\
0.75\end{array}$ & $\begin{array}{l}48.7 \\
79.7\end{array}$ & $\begin{array}{l}3.3 \\
3.3\end{array}$ & $\begin{array}{l}14.7 \\
21.4\end{array}$ & $\begin{array}{l}14.9 \\
16.1\end{array}$ & $\begin{array}{l}17.1 \\
18.4\end{array}$ \\
\hline & & Diodrast & & 6 & $\begin{array}{l}8.06 \\
7.43\end{array}$ & $\begin{array}{l}22.3 \\
23.4\end{array}$ & $\begin{array}{l}3.2 \\
3.2\end{array}$ & $\begin{array}{l}6.97 \\
7.30\end{array}$ & $\begin{array}{l}55.6 \\
54.1\end{array}$ & $\begin{array}{l}63.8 \\
62.0\end{array}$ \\
\hline \multirow[t]{2}{*}{5} & C. A. & Control & 1.49 & 5 & $\begin{array}{l}6.60 \\
5.35\end{array}$ & $\begin{array}{l}5.3 \\
6.3\end{array}$ & $\begin{array}{l}3.3 \\
3.3\end{array}$ & $\begin{array}{l}1.60 \\
1.91\end{array}$ & $\begin{array}{l}10.6 \\
10.2\end{array}$ & $\begin{array}{l}12.3 \\
11.8\end{array}$ \\
\hline & & Diodrast & & 6 & $\begin{array}{r}10.1 \\
8.0\end{array}$ & $\begin{array}{l}17.4 \\
22.3\end{array}$ & $\begin{array}{l}3.1 \\
3.1\end{array}$ & $\begin{array}{l}5.62 \\
7.20\end{array}$ & $\begin{array}{l}56.6 \\
56.6\end{array}$ & $\begin{array}{l}65.6 \\
65.6\end{array}$ \\
\hline \multirow[t]{2}{*}{6} & A. W. & Control & 1.45 & 6 & $\begin{array}{l}7.50 \\
3.56\end{array}$ & $\begin{array}{r}7.6 \\
16.0\end{array}$ & $\begin{array}{l}4.3 \\
4.3\end{array}$ & $\begin{array}{l}1.77 \\
3.72\end{array}$ & $\begin{array}{l}13.2 \\
13.3\end{array}$ & $\begin{array}{l}15.7 \\
15.8\end{array}$ \\
\hline & & Diodrast & & 7 & $\begin{array}{l}6.73 \\
5.46\end{array}$ & $\begin{array}{l}23.2 \\
33.0\end{array}$ & $\begin{array}{l}4.4 \\
4.4\end{array}$ & $\begin{array}{l}5.28 \\
7.50\end{array}$ & $\begin{array}{l}35.4 \\
41.0\end{array}$ & $\begin{array}{l}42.1 \\
48.8\end{array}$ \\
\hline \multirow[t]{2}{*}{7} & G. Mc. & Control & 1.91 & 6 & $\begin{array}{l}7.28 \\
7.57\end{array}$ & $\begin{array}{l}9.0 \\
9.9\end{array}$ & $\begin{array}{l}6.3 \\
6.3\end{array}$ & $\begin{array}{l}1.43 \\
1.57\end{array}$ & $\begin{array}{l}10.4 \\
11.9\end{array}$ & $\begin{array}{r}9.4 \\
10.8\end{array}$ \\
\hline & & Diodrast & & 7 & $\begin{array}{l}8.04 \\
6.76\end{array}$ & $\begin{array}{l}32.2 \\
32.7\end{array}$ & $\begin{array}{l}6.4 \\
6.4\end{array}$ & $\begin{array}{l}5.03 \\
5.10\end{array}$ & $\begin{array}{l}40.4 \\
34.6\end{array}$ & $\begin{array}{l}36.6 \\
31.5\end{array}$ \\
\hline \multirow[t]{2}{*}{8} & A. V. & Control & 1.69 & 6 & $\begin{array}{c}9.86 \\
10.0\end{array}$ & $\begin{array}{l}6.0 \\
5.2\end{array}$ & $\begin{array}{l}3.8 \\
3.8\end{array}$ & $\begin{array}{l}1.58 \\
1.37\end{array}$ & $\begin{array}{l}15.6 \\
13.7\end{array}$ & $\begin{array}{l}15.9 \\
14.0\end{array}$ \\
\hline & & Diodrast & & 7 & $\begin{array}{c}11.9 \\
6.75\end{array}$ & $\begin{array}{l}14.6 \\
25.7\end{array}$ & $\begin{array}{l}3.8 \\
3.8\end{array}$ & $\begin{array}{l}3.84 \\
6.76\end{array}$ & $\begin{array}{l}45.7 \\
45.6\end{array}$ & $\begin{array}{l}46.6 \\
46.5\end{array}$ \\
\hline \multirow[t]{2}{*}{9} & B. M. & Control & 1.45 & 4 & $\begin{array}{l}7.23 \\
7.50\end{array}$ & $\begin{array}{l}4.2 \\
5.0\end{array}$ & $\begin{array}{l}3.6 \\
3.6\end{array}$ & $\begin{array}{l}1.17 \\
1.39\end{array}$ & $\begin{array}{r}8.4 \\
10.4\end{array}$ & $\begin{array}{l}10.0 \\
12.4\end{array}$ \\
\hline & & Diodrast & & 5 & $\begin{array}{l}8.70 \\
9.00\end{array}$ & $\begin{array}{l}18.3 \\
18.6\end{array}$ & $\begin{array}{l}3.3 \\
3.3\end{array}$ & $\begin{array}{l}5.54 \\
5.63\end{array}$ & $\begin{array}{l}48.2 \\
50.6\end{array}$ & $\begin{array}{l}57.6 \\
60.1\end{array}$ \\
\hline \multirow[t]{2}{*}{10} & M.P. & Control & 1.70 & 7 & $\begin{array}{c}11.5 \\
2.73\end{array}$ & $\begin{array}{r}5.3 \\
18.6\end{array}$ & $\begin{array}{l}4.1 \\
4.1\end{array}$ & $\begin{array}{l}1.29 \\
4.53\end{array}$ & $\begin{array}{l}14.9 \\
12.4\end{array}$ & $\begin{array}{l}15.2 \\
12.7\end{array}$ \\
\hline & & Diodrast & & 8 & $\begin{array}{c}11.2 \\
2.36\end{array}$ & $\begin{array}{l}17.1 \\
79.0\end{array}$ & $\begin{array}{l}4.1 \\
4.1\end{array}$ & $\begin{array}{c}4.17 \\
19.3\end{array}$ & $\begin{array}{l}46.7 \\
45.4\end{array}$ & $\begin{array}{l}47.6 \\
46.3\end{array}$ \\
\hline \multirow[t]{2}{*}{11} & J.A. & Control & 1.71 & 6 & $\begin{array}{l}7.43 \\
7.68\end{array}$ & $\begin{array}{l}8.1 \\
8.2\end{array}$ & $\begin{array}{l}4.1 \\
4.1\end{array}$ & $\begin{array}{l}1.98 \\
2.00\end{array}$ & $\begin{array}{l}14.8 \\
15.4\end{array}$ & $\begin{array}{l}15.0 \\
15.6\end{array}$ \\
\hline & & Diodrast & & 7 & $\begin{array}{l}12.1 \\
11.7\end{array}$ & $\begin{array}{l}15.6 \\
18.2\end{array}$ & $\begin{array}{l}4.1 \\
4.1\end{array}$ & $\begin{array}{l}3.81 \\
4.44\end{array}$ & $\begin{array}{l}46.0 \\
51.9\end{array}$ & $\begin{array}{l}46.4 \\
52.4\end{array}$ \\
\hline
\end{tabular}


TABLE III

Uric acid and urea clearances and creatinine excretion

\begin{tabular}{|c|c|c|c|c|c|c|}
\hline \multirow{3}{*}{ No.* } & \multicolumn{4}{|c|}{ Clearance } & \multirow{2}{*}{\multicolumn{2}{|c|}{$\begin{array}{c}\text { Creatinine excretion per } 30 \text { minutes } \\
\text { per } 1.73 \mathrm{sq} . \mathrm{m} .\end{array}$}} \\
\hline & \multicolumn{2}{|c|}{ Uric acid } & \multicolumn{2}{|c|}{ Urea } & & \\
\hline & Control & Diodrast & Control & Diodrast & Control & Diodrast \\
\hline $\begin{array}{r}1 \\
2 \\
3 \\
4 \\
5 \\
6 \\
7 \\
8 \\
9 \\
10 \\
11\end{array}$ & $\begin{array}{r}15.4 \\
17.8 \\
14.7 \\
18.3 \\
8.8 \\
10.1 \\
17.1 \\
18.4 \\
12.3 \\
11.8 \\
15.7 \\
15.8 \\
9.4 \\
10.8 \\
15.9 \\
14.0 \\
10.0 \\
12.4 \\
15.2 \\
12.7 \\
15.0 \\
15.5\end{array}$ & $\begin{array}{l}\quad c c . \text { pe } \\
43.3 \\
50.0 \\
53.1 \\
54.7 \\
47.4 \\
45.3 \\
63.6 \\
62.0 \\
65.6 \\
65.6 \\
42.1 \\
48.8 \\
36.6 \\
31.5 \\
46.6 \\
46.5 \\
57.6 \\
60.1 \\
47.6 \\
46.3 \\
46.4 \\
52.4\end{array}$ & $\begin{array}{l}\text { sq. m. } \\
83.4 \\
94.3 \\
70.8 \\
93.8 \\
73.5 \\
71.8 \\
49.6 \dagger \\
47.3 \dagger \\
63.6 \\
56.8 \\
73.3 \\
72.0 \\
80.1 \\
83.6 \\
94.3 \\
88.6 \\
53.7 \\
66.4 \\
73.6 \\
55.0 \\
92.4 \\
83.6\end{array}$ & $\begin{array}{r}86.0 \\
75.5 \\
97.7 \\
73.6 \\
89.9 \\
75.1 \\
79.4 \\
67.9 \\
106.0 \\
97.8 \\
68.5 \\
73.1 \\
80.8 \\
75.6 \\
87.4 \\
73.3 \\
99.9 \\
89.5 \\
77.0 \\
61.5 \\
97.0 \\
90.6\end{array}$ & $\begin{array}{l}24 \\
25 \\
25 \\
24 \\
24 \\
24 \\
26 \\
25 \\
25 \\
23 \\
24 \\
24 \\
23 \\
23 \\
25 \\
22 \\
24 \\
27 \\
24 \\
21 \\
29 \\
25\end{array}$ & $\begin{array}{r}26 \\
24 \\
27 \\
21 \\
29 \\
22 \\
26 \\
24 \\
24 \\
23 \\
22 \\
21 \\
23 \\
23 \\
21 \\
21 \\
20 \\
25 \\
21 \\
22 \\
19 \\
22 \\
27\end{array}$ \\
\hline Average & $14.0 \pm 2.9$ & $50.6 \pm 9.1$ & $76.2 \pm 13.0$ & $82.9 \pm 12.0$ & $24 \pm 1.7$ & $23 \pm 2.4$ \\
\hline
\end{tabular}

* Correspond with the numbers in Table II.

† Standard clearances. These values are not included in the statistical evaluation of the data.

acid excretion (the uric acid being determined by the Folin 1933 method) averages $23.6 \mathrm{cc}$. per minute. This figure is a little high. This may be due to the fact that their average plasma uric acid value is $3.16 \mathrm{mgm}$. per cent which is lower than most values reported for plasma uric acid. An average normal uric acid clearance has also been calculated ${ }^{6}$ from Gärdstam's data (15). In this study, the urine uric acid was determined by the Folin and Wu method (16) and the plasma by the Folin 1922 method (10). From 48 clearance periods, on 34 patients with normal kidney function, one obtains an average clearance of 12.9 cc. per minute. Gärdstam reported an average plasma uric acid level of $4.0 \mathrm{mgm}$. per cent. Coombs et al. (2) have also reported a uric acid clearance which averages $11.1 \mathrm{cc}$. per minute per 1.73 sq. $\mathrm{m}$. in 11 cases. They used the Benedict and Behre (17) method for the de-

\footnotetext{
- Only those clearances which were performed in the first period in the morning and only those with a urine flow greater than $0.5 \mathrm{cc}$. per minute were averaged.
}

termination of uric acid. Their average plasma uric acid value is not reported.

The lowest uric acid clearances (6.93 cc. per minute) have been reported by Br $\phi$ chnerMortensen (18 to 20). He has used the reduction of ferricyanide at $\mathrm{pH} 11$ as a method for the determination of uric acid. It should be noted, however, that Brøchner-Mortensen's reported values for serum uric acid are high. They average $6.35 \mathrm{mgm}$. per cent in 25 normal women and $7.62 \mathrm{mgm}$. per cent in 25 normal men. These high plasma values (and thereby the low uric acid clearances) may be due to a possible source of error due to glucose, as pointed out by Bulger and Johns (21), in the ferricyanide method used by Brøchner-Mortensen. Bulger and Johns (using a combined ferricyanide and uricase method) report an average plasma uric acid value in the groups which they studied as 3.5 mgm. per cent for females and $4.4 \mathrm{mgm}$. per cent for males. If one assumes that BrøchnerMortensen's urine uric acid values are of the 
correct order of magnitude, it is possible for the purposes of discussion to correct his plasma uric acid values to approximately those reported by Bulger and Johns. Such a correction would increase Brфchner-Mortensen's average uric acid clearance from 6.9 to $12.2 \mathrm{cc}$. This figure is of the same order as most of those previously reported.

Except then, for Brøchner-Mortensen's value for which there may be an explanation, and the value reported by Berglund and Frisk, the data show a rather good agreement. This agreement actually becomes somewhat enhanced if one considers the low esteem in which uric acid methods have been held. ${ }^{7}$ At least 3 different groups of investigators, using different methods for the determination of uric acid have now reported uric acid clearances of the same order of magnitude. It appears probable, therefore, that the normal uric acid clearance lies somewhere between 11 and $15 \mathrm{cc}$. per minute.

The very high uric acid clearances previously reported from this laboratory are in all probability due to the simultaneous presence and excretion of diodrast. The data presented in the previous paper (1) are, however, still pertinent and any datum in that paper can be compared with any other datum reported in that paper, since the same amount of diodrast was given in each case. The data are, however, erroneous as absolute values. As an approximation, the uric acid clearances can be corrected by dividing by 2 .

The data presented herein indicate that diodrast must be added to the list of substances which increase the excretion of uric acid. The mechanism of this reaction or action, however, is still unknown. It is known, however, that diodrast is excreted by the kidney tubule (22). Most probably this excretion inhibits the reabsorption of uric acid. But it is also theoretically possible that uric acid is also excreted by the tubule and the increased activity of the tubule required to excrete the diodrast is reflected

\footnotetext{
7 Apparently, many investigators consider them both inadequate and inaccurate. This certainly cannot be attributed to any lack of effort in this direction. One of us ' (R. W. B.) has collected a bibliography of 280 titles of papers dealing with the quantitative determination of uric acid in blood and urine.
}

in an increased excretion of uric acid. However, we are more inclined to the view that the excretion of diodrast inhibits the reabsorption of uric acid.

It also seems probable that diodrast is affecting one specific mechanism or portion of the kidney tubule or both since the reabsorption of uric acid is not affected by the simultaneous maximal reabsorption of glucose nor is there any significant alteration in the urea clearance or in the creatinine excretion when diodrast is given. These data also indicate that diodrast is excreted by one specific mechanism or portion of the tubule and that any conclusions drawn as to tubular function from the excretion of diodrast may only apply to one portion or mechanism of the tubule. On the other hand, it may be possible that larger amounts of diodrast than those given in these experiments may also have some effect upon the urea clearance.

\section{SUMMARY}

The uric acid clearance as determined in the normal woman, 1 to 8 days postpartum, averaged $15.4 \pm 3.2 \mathrm{cc}$. per minute per 1.73 sq. $\mathrm{m}$. in a series of 9 subjects, and $14.0 \pm 2.9 \mathrm{cc}$. per minute per 1.73 sq. $\mathrm{m}$. in another series of 11 subjects. There is no significant difference between these values. The injection of diodrast resulted in an increased excretion of uric acid. The average uric acid clearance in the 11 subjects described above increased to $50.6 \pm 9.1 \mathrm{cc}$. per minute per 1.73 sq. $\mathrm{m}$. when a given amount of diodrast was being excreted simultaneously. The diodrast did not have any effect upon the urea clearance or the creatinine excretion. In contrast, the injection of hypertonic solutions of glucose exerted no effect upon the excretion of uric acid.

Dr. H. W. Smith has recently called our attention to a chapter on gout by J. H. Talbot in Oxford Medicine, vol. IV, part I, chapter IV, Oxford University Press, New York, 1943, in which a similar effect of diodrast upon uric acid is described.

We wish to express our appreciation and thanks for the aid and suggestions received during the course of this work from Dr. H. J. Stander and Dr. Vincent du Vigneaud. The nursing staff of the Lying-In Hospital has been most cooperative in assisting in the collection of blood and urine specimens. Particular thanks are extended to Miss $\mathrm{L}$. Woermbke, R.N., Miss A. Klubko, R.N., Mrs. M. Carter, 
R.N., and Mrs. W. McDermott. Many of the uric acid and most of the creatinine analyses were performed by Miss Hertha H. Taussky, M.S., and many of the urea analyses by Mr. Nelson Osterberg.

\section{BIBLIOGRAPHY}

1. Schaffer, N. K., Dill, L. V., and Cadden, J. F., Uric acid clearance in normal pregnancy and preeclampsia. J. Clin. Invest., 1943, 22, 201.

2. Coombs, F. S., Pecora, L. J., Thorogood, E., Consolazio, W. V., and Talbott, J. H., Renal function in patients with gout. J. Clin. Invest., 1940, 19, 525.

3. Foa, P. P., and Foa, N. L., A simple method for determining effective renal blood flow and tubular excretory mass in man. Proc. Soc. Exper. Biol. and Med., 1942, 51, 375.

4. Wu, H., Separate analyses of the corpuscles and the plasma. J. Biol. Chem., 1922, 51, 21.

5. Van Slyke, D. D., and Kugel, V. H., Improvements in manometric micro-Kjeldahl and blood urea methods. J. Biol. Chem., 1933, 102, 489.

6. Folin, $O$., On the determination of creatinine and creatine in urine. J. Biol. Chem., 1914, 17, 469.

7. Summerson, W. H., A simplified test-tube photoelectric colorimeter, and the use of the photoelectric colorimeter in colorimetric analysis. J. Biol. Chem., 1939, 130, 149.

8. Folin, O., Standardized methods for the determination of uric acid in unlaked blood and in urine. J. Biol. Chem., 1933, 101, 111.

9. Folin, O., The preparation of sodium tungstate free from molybdate, together with a simplified process for the preparation of a correct uric acid reagent. J. Biol. Chem., 1934, 106, 311.
10. Folin, O., A system of blood analysis. Supplement IV. A revision of the method for determining uric acid. J. Biol. Chem., 1922, 54, 153.

11. Folin, O., and Marenzi, A. D., The preparation of uric acid reagent completely free from phenol reagent. J. Biol. Chem., 1929, 83, 109.

12. Schaffer, N. K., and Stander, H. J., True uric acid in hyperuricemia of pre-eclampsia and eclampsia. Proc. Soc. Exper. Biol. and Med., 1940, 45, 180.

13. Schaffer, N. K., The determination of uric acid in urine with crude uricase. J. Biol. Chem., 1944, $153,163$.

14. Berglund, H., and Frisk, A. R., Uric acid elimination in man. Acta Med. Scandinav., 1935, 86, 233.

15. Gärdstam, R., Über Harnsäureausscheidung bei Kreatininbelastung. Acta Med. Scandinav., 1935, suppl. 67.

16. Folin, O., and Wu, H., A revised colorimetric method for the determination of uric acid in urine. J. Biol. Chem., 1919, 38, 459.

17. Benedict, S. R., and Behre, J. A., The analysis of whole blood. III. Determination and distribution of uric acid. J. Biol. Chem., 1931, 92, 161.

18. Brøchner-Mortensen, $K$., Uric Acid in Blood and Urine. Levin and Munksgaard, Copenhagen, 1937.

19. Brøchner-Mortensen, $\mathrm{K}$., Uric acid in blood and urine. Acta Med. Scandinav., 1937, suppl. 84.

20. Brøchner-Mortensen, $K$., The uric acid content in blood and urine in health and disease. Medicine, 1940, 19, 161.

21. Bulger, H. A., and Johns, H. E., The determination of plasma uric acid. J. Biol. Chem., 1941, 140, 427.

22. Smith, H. W., Goldring, W., and Chasis, H., The measurement of the tubular excretory mass, effective blood flow and filtration rate in the normal human kidney. J. Clin. Invest., 1938, 17, 263. 